\title{
Total saponins from Lilium lancifolium: a promising alternative to inhibit the growth of gastric carcinoma cells
}

\author{
Yin-Yu Zhang ${ }^{1 *}$, Lin-Ming Luo ${ }^{1 *}$, Yu-Xiang Wang ${ }^{1}$, Neng Zhu², Tan-Jun Zhao', and Li Qin ${ }^{1 凶}$ \\ 1. Division of Stem Cell Regulation and Application, School of Pharmacy, Hunan University of Chinese Medicine, Changsha, China \\ 2. The First Hospital of Hunan University of Chinese Medicine, Changsha, China \\ * These authors contributed equally to this work. \\ $\square$ Corresponding author: Dr. Li Qin. Email: 1qin@hnucm.edu.cn \\ (1) The author(s). This is an open access article distributed under the terms of the Creative Commons Attribution License (https://creativecommons.org/licenses/by/4.0/). \\ See http://ivyspring.com/terms for full terms and conditions.
}

Received: 2019.11.19; Accepted: 2020.03.30; Published: 2020.04.27

\begin{abstract}
Bulbus Lilii, as a medicinal and edible plant, has anti-inflammatory, anti-oxidative and immunopotentiating pharmacological activities, which seems to be therapeutic on cancer prevention. The purpose of this study was to investigate the effects of total saponins from Lilium lancifolium (TSLL) on proliferation, apoptosis and migration of human gastric carcinoma cells lines SGC-7901 and HGC-27 and its underlying mechanism. The results showed that TSLL inhibited the proliferation of gastric carcinoma cells by suppressing the level of proliferating cell nuclear antigen (PCNA) and increased p21 level. TSLL induced cells apoptosis by up-regulating expression of pro-apoptotic protein Bax and down-regulating anti-apoptotic protein Bcl-2 expression. Meanwhile, TSLL remarkably inhibited cell migration and invasion, decreased matrix metalloproteinase-2 (MMP-2) expression and increased tissue inhibitor of metalloproteinases-1 (TIMP-1) expression. Notably, TSLL had stronger anti-cancer effect on undifferentiated HGC-27 cells than differentiated SGC-7901 cells. Accordingly, TSLL might be a promising candidate to prevent and suppress the growth of gastric carcinoma cells.
\end{abstract}

Key words: Total saponins from Lilium lancifolium; proliferation; apoptosis; migration; Gastric Carcinoma Cells

\section{Introduction}

Gastric carcinoma is one of the most common malignant cancers, and its mortality ranks third in the world in cancer [1]. The majority of patients with gastric carcinoma are diagnosed in the advanced stage due to the lack of early diagnosis. Clinically, the most frequent cause of treatment failure following surgery for gastric carcinoma is peritoneal dissemination, mainly caused by the seeding of free cancer cells from the primary gastric carcinoma, which is the most common type of spread [2]. Moreover, its high recurrence rate and high metastasis rate are the most important reasons for the low survival rate of gastric carcinoma patients [3]. Therefore, effective drugs capable of preventing or treating gastric carcinoma are needed urgently to improve the therapeutic outcomes. Herein, we attempted to develop a new compound from natural products against gastric carcinoma to avoid the side effects, such as difficult to diagnose and high metastatic potential.

Bulbus Lilii, from a kind of perennial bulbiferous plant in the genus Lilium of the family Liliaceae, not only has high nutritional value with rich protein, dietary fiber and vitamins, is also rich in selenium, calcium, magnesium, zinc and other trace elements. As a traditional Chinese medicine, Lilii mainly contains steroidal saponins, alkaloids, organic acids and polysaccharides [4]. Steroidal saponins have been identified in lily bulbs [5]. As one of the main biological active ingredients in lily, it qualified with 
many biological activities, including anti-inflammatory, anti-bacterial, anti-oxidation [6]. However, up to date, there are few reports on the anticancer activity of Total saponins of Lilium lancifolium (TSLL). Our previous study found that TSLL inhibited the proliferation, migration and invasion of lung cancer A549 cells lines and induced apoptosis. Here, we explored the effects and potential mechanism of TSLL on gastric carcinoma cells, so as to provide a new strategy for the treatment of gastric carcinoma patients.

\section{Materials and methods}

\section{Chemicals}

Dulbecco's Modified Eagle Medium (DMEM), fatal bovine serum (FBS), $0.25 \%$ trypsin-EDTA, and phosphate buffered saline (PBS) were purchased from Gibco (Grand Island, NY, USA). Matrigel was purchased from BD Biosciences (San Jose, CA, USA). Bovine serum protein (BSA), fibronectin (FN), and $0.1 \%$ Crystal Violet staining solution were purchased from Solarbio (Beijing, China). The cell counting kit-8 (CCK-8) was purchased from Dojindo Laboratories (Kumamoto, Japan). YF488 Click-iT EdU imaging kit, YF488-Annexin V/PI apoptosis detection kit, and Hoechst 33342 were obtained from US Everbright (Silicon Valley, USA). Anti-PCNA, anti-P21, anti-Bcl-2, anti-Bax, anti-MMP-2, anti-TIMP-1,
anti-E-cadherin, and anti-GAPDH rabbit polyclonal antibodies were purchased from Proteintech Group (Chicago, IL, USA). Anti-activated-Casepase-3 and anti-Vimentin rabbit polyclonal antibodies were purchased from Bioworld Technology (St. Louis Park, MN, USA).

\section{Sample Preparation}

The fresh bulbs of Lilium lancifolium Thunb (provided by Yao Sheng Tang (Hunan) Pharmaceutical Co., Ltd.) were extracted with $70 \%$ ethanol and concentrated by heating. To obtain the concentrated extracts, the solution was repeatedly extracted with chloroform, ethyl acetate and $n$-butanol in turn. Each round lasted for $2 \mathrm{~h}$ until the water layer is almost colorless. Then, the solution was concentrated by a rotary evaporator and dried by evaporating dish. The crude extract was further purified by using column chromatography. The dried $n$-butanol extract was dissolved in distilled water and filled into a prepared low-pole AB-8 macro-porous adsorption resin column. The column was successively eluted with $4 \mathrm{~L}$ distilled water, $10 \%, 30 \%$, $50 \%, 70 \%$ and $100 \%$ ethanol. The $70 \%$ ethanol eluent was collected, concentrated and dried to obtain solid total saponins extract (Fig. 1). TSLL was a test sample and cisplatin (CDDP) was used as a reference to compare the anti-cancer effect of TSLL.

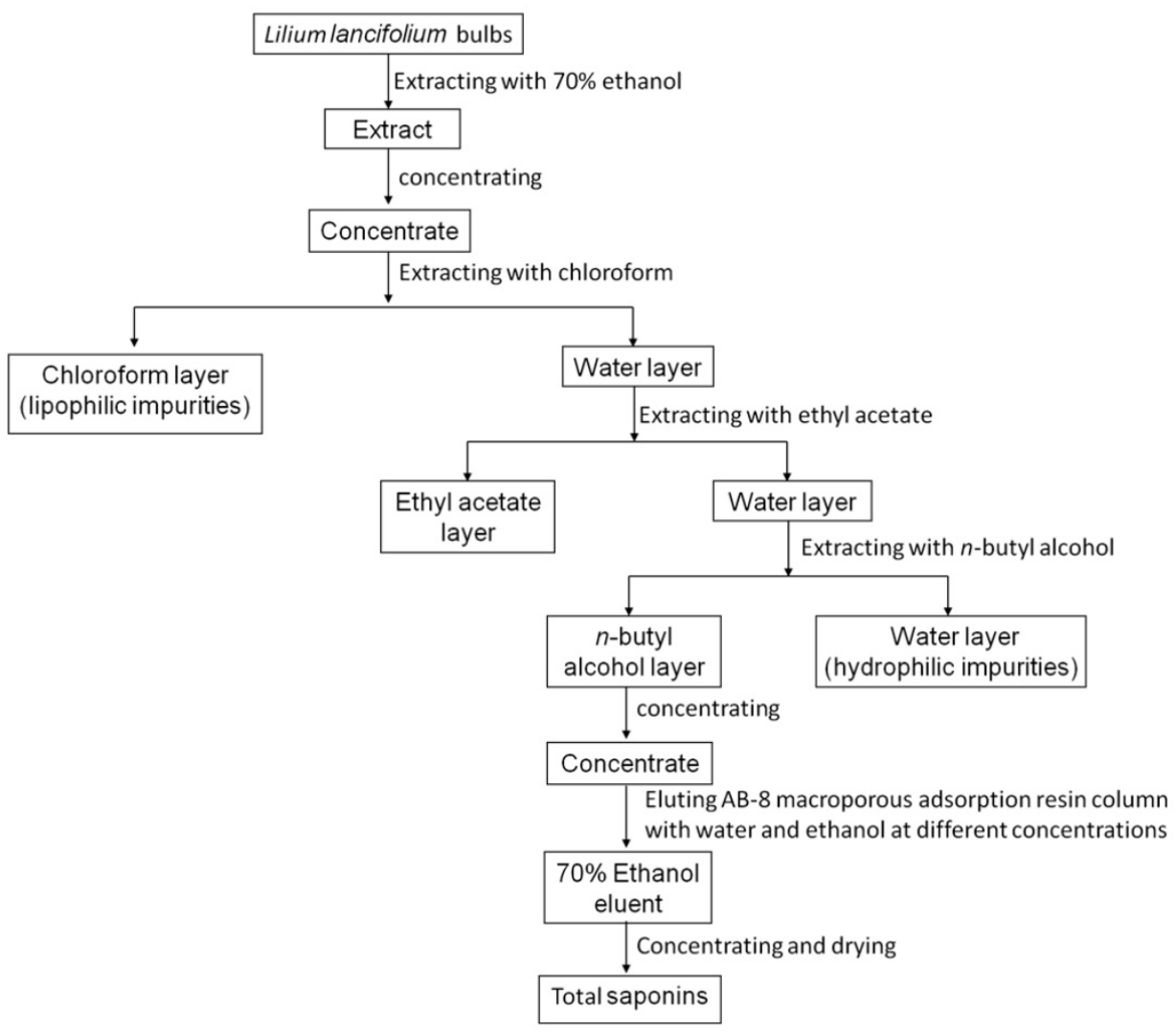

Figure 1. The flow of TSLL sample preparation. 


\section{Cell culture and treatment}

Human gastric carcinoma cell lines SGC-7901 (moderate differentiated) and HGC-27 (undifferentiated) were purchased from the Cell Bank of the Chinese Academy of Sciences (Shanghai, China), and were cultured at $37^{\circ} \mathrm{C}$ and humidified $5 \% \quad \mathrm{CO}_{2}$ incubator with DMEM high glucose medium containing $10 \% \mathrm{FBS}, 100 \mathrm{mg} / \mathrm{mL}$ penicillin, and 100 $\mathrm{mg} / \mathrm{mL}$ streptomycin. Culture medium was changed every 2-3 days.

\section{Cell viability assay}

SGC-7901 or HGC-27 cells in the logarithmic growth period were inoculated in 96-well culture plate at density of $1 \times 10^{5}$ cells $/ \mathrm{mL}$. After incubation in a humidified incubator with $5 \% \mathrm{CO}_{2}$ at $37^{\circ} \mathrm{C}$ for $24 \mathrm{~h}$ and added starvation for $12 \mathrm{~h}$, different concentration of TSLL $(0,25,50,100,200$ and $400 \mu \mathrm{g} / \mathrm{mL})$ and CDDP $(4 \mu \mathrm{g} / \mathrm{mL})$ were used to treat cells for $24 \mathrm{~h}, 48 \mathrm{~h}$ and 72 $\mathrm{h}$, respectively. In addition, cells with complete medium containing $0.3 \%$ ethanol were served as negative control. After treatment, the medium was removed, $100 \mu \mathrm{L} \mathrm{10 \%} \mathrm{CCK-8} \mathrm{solution} \mathrm{was} \mathrm{added,} \mathrm{and}$ cells were incubated with CCK8 for $50 \mathrm{~min}$. The optical density (OD) of yellow formazan product was measured by using a microplate reader (Elx 800, BioTek, USA) at $450 \mathrm{~nm}$ and generated by control taken as $100 \%$.

$$
\text { viable cells }(\%)=\frac{O D_{\text {Treatment group }}}{O D_{\text {Control group }}} \times 100 \%
$$

\section{Clone formation assay}

SGC-7901 and HGC-27 cells (300 cells/well) were planted into 6-well culture plate with DMEM medium for $24 \mathrm{~h}$ and were treated with various concentrations of TSLL $(0,25,50,100,200,400 \mu \mathrm{g} / \mathrm{mL})$ or $0.3 \%$ ethanol as a vehicle control. The growth condition of cells was observed every 2 days under microscope, and the medium was renewed every 4 days until the visible clones appeared. The medium was discarded and the cells were carefully washed with PBS twice. After being fixed with methanol for $15 \mathrm{~min}$, the cells were stained with $0.1 \%$ crystal violet dyeing solution for 15 min before washing with PBS and air-drying. The clones with more than 50 cells were counted with an ordinary optical microscope and the clone formation rate was calculated with the following formula:

clone formation rate(\%)

$$
=\frac{\text { number of cell clones }}{\text { number of inoculated cells }} \times 100 \%
$$

\section{EdU staining}

A Click-iT EdU kit was used according to the manufacturer's instructions. SGC-7901 and HGC-27 cells at a density of $1 \times 10^{4}$ cells/well were seeded in 96-well plates with TSLL $(25,50,100,200$ and 400 $\mu \mathrm{g} / \mathrm{mL}$ ), while the control well substituted $0.3 \%$ ethanol for drug. Then, $50 \mu \mathrm{moL}$ EdU solutions were added to the cells, and incubated at $37^{\circ} \mathrm{C}$ for another 2 h. After collection, the cells were fixed with $4 \%$ paraformaldehyde for $15 \mathrm{~min}$, and infiltrated by using Triton X-100 solution for $20 \mathrm{~min}$ at room temperature in the dark. In order to detect cells proliferation, the fixed cells were then stained with Click-iT reaction mixture and cell nuclei were stained with $1 \mu \mathrm{g} / \mathrm{mL}$ DAPI in the dark at room temperature for $30 \mathrm{~min}$. The stained cells were observed under an inverted fluorescence microscope, and the fluorescent cells were counted by using Image Pro Plus 6.0 (IPP). The DNA synthesis rate was calculated by using following equation:

$$
\text { DNA synthesis rate }=\frac{g}{b} \times 100 \%
$$

( $g$ represents the number of green fluorescent cells, and $\mathrm{b}$ represents the number of blue fluorescent cells)

\section{Annexin V/PI double staining}

Annexin V/propidium iodide (PI) double staining assay was done based on the manufacturer's instructions. In brief, SGC-7901 and HGC-27 cells were planted into 6-well culture plate at a density of $1.0 \times 10^{5}$ cells per well, and pre-incubated in an incubator of $37{ }^{\circ} \mathrm{C}, 5 \% \mathrm{CO}_{2}$ for $24 \mathrm{~h}$. Different concentrations of TSLL $(100,200,400 \mu \mathrm{g} / \mathrm{mL})$ and CDDP $(10 \mu \mathrm{g} / \mathrm{mL})$ were added to corresponding well while removing the original medium. Additionally, control well was treated with $0.3 \%$ ethanol. After $36 \mathrm{~h}$ of treatment, medium was removed and cells were immobilized with $4 \%$ polyoxymethylene for $15 \mathrm{~min}$. Annexin V/PI double staining was used to determine apoptosis.

\section{Hoechst 33342 staining}

In order to investigate the cells apoptosis, morphological analysis was performed by Hoechest 33258 staining. SGC-7901 and HGC-27 cells were seeded in a 96-well tissue culture plate at a density of $1 \times 10^{4}$ cells/well. Cells were treated with different concentrations of TSLL $(100,200,400 \mu \mathrm{g} / \mathrm{mL}$ and CDDP $(10 \mu \mathrm{g} / \mathrm{mL})$, and control well was treated with $0.3 \%$ ethanol. After $36 \mathrm{~h}$ of treatment, the cells were incubated with $100 \mu \mathrm{L}$ Hoechst 33258 at $37^{\circ} \mathrm{C}$ for $20 \mathrm{~min}$, followed by observation under a fluorescence microscope. Strong fluorescence can be observed in the nuclei of apoptotic cells, while weak fluorescence was observed in non-apoptotic cells. 


\section{Wound healing assay}

SGC-7901 and HGC-27 cells were seeded into 6-well culture plate for $24 \mathrm{~h}$ and the cells were followed by starvation overnight. Wounded by scratching with white pipette tips, the cells were incubated with condition medium containing 1\% FBS and then received various treatments of TSLL $(0,25$, 50,100 and $200 \mu \mathrm{g} / \mathrm{mL}$ ). The number of migrated cells was determined under an inverted microscopy at $6 \mathrm{~h}$, $12 \mathrm{~h}$ and $24 \mathrm{~h}$.

\section{Transwell migration assay}

In vitro invasion assay was performed by using transwell plates (Guangzhou Jet Bio-Filtration, Co., Ltd) with $8 \mu \mathrm{m}$ pores. The cells $\left(1 \times 10^{6}\right.$ cells $)$ with TSLL $(0,25,50,100$ and $200 \mu \mathrm{g} / \mathrm{mL})$ and serum-free DMEM medium were added to the upper chamber of the transwell plates that were pre-coated with matrigel. Then DMEM medium containing $10 \%$ FBS as a chemo-attractant was added to the lower chamber. After incubation for $48 \mathrm{~h}$, cells on the upper surface were removed by using cotton wool and the rest cells were fixed with methanol and stained with $0.5 \%$ crystal violet. Images were captured and the cells were counted by measuring the optical density (OD) value of each well at $570 \mathrm{~nm}$ with a microplate reader.

\section{Cell adhesion assay}

The 96-well plates were coated with $50 \mu \mathrm{L}$ fibronectin at $4^{\circ} \mathrm{C}$ for $6 \mathrm{~h}$, and then washed twice with PBS and blocked with serum-free DMEM+2\% BSA for $30 \mathrm{~min}$ at $37{ }^{\circ} \mathrm{C}$. SGC-7901 and HGC-27 cells were treated with different concentrations of TSLL $(0,25$, 50,100 and $200 \mu \mathrm{g} / \mathrm{mL}$ ) for $24 \mathrm{~h}$ at $37^{\circ} \mathrm{C}$ in a humidified incubator supplemented with $5 \% \mathrm{CO}_{2}$. To remove the non-adherent cells, plates were gently washed twice with PBS. Then, $100 \mu \mathrm{L}$ of DMEM medium and $10 \mu \mathrm{L}$ CCK-8 solution were added to each well. After incubation for $50 \mathrm{~min}$, the OD at 450 $\mathrm{nm}$ of each well was measured with a microplate reader. The cell adhesion ratio was calculated according to the following formula:

$$
\text { Cell adhension ratio }=\frac{O D_{450 \text { treated group }}}{O D_{450 \text { untreated group }}} \times 100 \%
$$

\section{Western blotting}

Western blotting was used to detect the proteins that were related to cell proliferation, apoptosis and invasion and metastasis in gastric carcinoma cells SGC-7901 and HGC-27. Cells were harvested and lysed in cell-lysis buffer. Protein concentrations were quantified by a BCA protein assay according to the manufacturer's instructions. Twenty micrograms of each sample were separated by $12 \%(\mathrm{v} / \mathrm{v})$ SDS-PAGE gel, and then the protein samples were transferred onto polyvinylidene difluoride (PVDF) membranes. The resultant membrane was incubated with Tris-buffered saline and Tween-20 (TBST) containing $5 \%$ skim milk for blocking for $2 \mathrm{~h}$. Membranes were incubated at $4^{\circ} \mathrm{C}$ overnight with primary antibody (1:1000) and washed three times with TBST buffer. The membranes were then incubated with the horseradish peroxidase-conjugated secondary antibody at room temperature for $2 \mathrm{~h}$. Protein bands were visualized using ECL reagent.

\section{Statistical analysis}

All values were presented as the mean $\pm S D$, and statistical analyses were performed using GraphPad Prism 7 (GraphPad, San Diego, CA, USA). A one-way analysis of variance (ANOVA) was employed to analyze the differences within multiple groups and $P$ $<0.05$ was considered significant.

\section{Results}

\section{TSLL has cytotoxic effects on human gastric carcinoma cells}

The total saponins from the fresh bulbs of Lilium lancifolium Thunb were isolated successfully. To explore the role of TSLL in different stages of gastric carcinoma, SGC-7901 and HGC-27 cells were applied in this study [7]. We found that TSLL could significantly inhibit the survival rate of SGC-7901 cells at the concentration of 200 and $400 \mu \mathrm{g} / \mathrm{mL}(P<0.001)$ (Fig. 2A), and had the similar inhibitory effect on HGC-27 cells $(P<0.001)$ at $50-400 \mu \mathrm{g} / \mathrm{mL}$ TSLL (Fig. 2B). Meanwhile, 100-400 $\mu \mathrm{g} / \mathrm{mL}$ TSLL treatment for $48 \mathrm{~h}$ or $72 \mathrm{~h}$ could significantly inhibit SGC-7901 cells survival rate $(P<0.05, P<0.01, P<0.001)$, while $50-400 \mu \mathrm{g} / \mathrm{mL}$ TSLL had the similar effect on HGC-27 cells. Thus, TSLL inhibits the proliferation of SGC-7901 and HGC-27 cells in a time- and dose-dependent manner. Notably, the inhibitory effect of TSLL on HGC-27 cells was stronger than that of SGC-7901 cells (Fig. 2C). These data indicate that HGC-27 cells appeared to be more sensitive to TSLL than SGC-7901 cells.

\section{TSLL inhibits the proliferation of gastric carcinoma cells}

As shown in Fig. 3, TSLL significantly reduced the proliferation ability of gastric carcinoma cells. Compared to the control group, TSLL also dramatically inhibited the clone formation of SGC-7901 cells at the concentration range of 50-400 $\mu \mathrm{g} / \mathrm{mL}(P<0.001)$ (Fig. 3A). There was almost no colony formation in the $200-400 \mu \mathrm{g} / \mathrm{mL}$ TSLL-treated group, suggesting that TSLL not only inhibited the proliferation of SGC-7901 cells, but also induced cell death or exerted direct cytotoxicity at high 
concentrations. TSLL also showed the similar effect on HGC-27 cells (Fig. 3B). Furthermore, the DNA synthesis rate of SGC-7901 (Fig. 3C) and HGC-27 (Fig. 3D) cells was inhibited by TSLL in a dose-dependent manner. Undoubtedly, the effect of TSLL on DNA synthesis of SGC-7901 and HGC-27 cells was different. $400 \mu \mathrm{g} / \mathrm{mL}$ TSLL exhibited the maximum DNA synthesis inhibition rate of $15.60 \%$ in SGC-7901 cells, while $26.15 \%$ in HGC-27 cells. In line with previous results, the inhibitory effect of TSLL on HGC-27 cell proliferation is stronger than that on SGC-7901 cells (Fig. 3E and 3F).

\section{TSLL inhibits the proliferation of gastric carcinoma cells by down-regulating PCNA expression and promoting p21 expression}

It is known that proliferating cell nuclear antigen (PCNA)/p21 signaling pathway is one of the key pathways for cell replication. As a cyclin-dependent kinases (CDKs) inhibitor protein, p21 can not only regulate cell-cycle, but also participate in cells apoptosis. These effects are largely dependent on the antagonistic effects between p21 and PCNA. For example, p21 inhibits the synthesis of DNA by directly interacting with PCNA binding proteins and competing for PCNA, which is required in DNA repairing $[8,9]$. Herein, we found that TSLL (200 and $400 \mu \mathrm{g} / \mathrm{mL}$ ) inhibited the expression of PCNA in both SGC-7901 cell lines and HGC-27 cell lines.

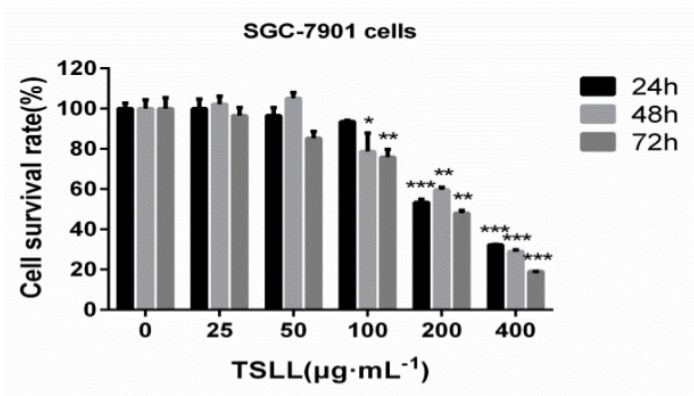

(A)

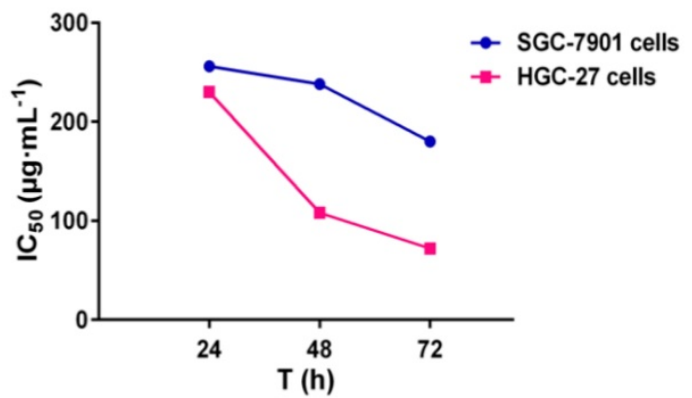

Additionally, as shown in Fig. 4B, TSLL (200 and 400 $\mu \mathrm{g} / \mathrm{mL}$ ) treatment significantly increased the expression of p21 in SGC-7901 cells $(P<0.05, P<$ $0.001)$.

\section{TSLL induced apoptosis of gastric carcinoma cells}

As shown in Fig.5, TSLL (200 and $400 \mu \mathrm{g} / \mathrm{mL}$ ) treatment in SGC-7901 and HGC-27 cells for 36 hours induced numerous amount of apoptotic cells with strong green fluorescence (Fig. 5A and 5B). It is worth noting that the green fluorescence density in 400 $\mu \mathrm{g} / \mathrm{mL}$ TSLL treatment group was significantly higher than that in $200 \mu \mathrm{g} / \mathrm{mL}$ TSLL treatment group. These results indicate that high concentrations of TSLL can activate the apoptotic pathway in gastric carcinoma cells. Meanwhile, Hoechst 33342 staining showed TSLL treatment induced typical apoptotic phenotypic changes, such as chromatin condensation, nuclear condensation and even cleavage, especially in SGC-7901 cells treatment. The apoptotic cell rates of the three groups with different concentration of TSLL $(100,200$ and $400 \mu \mathrm{g} / \mathrm{mL})$ were $8.11 \%, 19.90 \%(P<$ $0.01)$ and $44.75 \%(P<0.001)$, respectively. Similar results were also observed in HGC cells treated with TSLL (100, 200 and $400 \mu \mathrm{g} / \mathrm{mL}$ ), and the apoptotic cell rates of three group were $9.37 \%, 27.90 \%(P<0.001)$ and $46.46 \%(P<0.001)$, respectively.

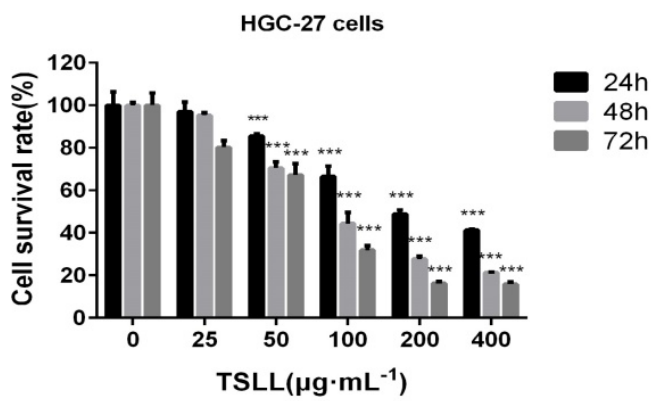

(B)

(C)

Figure 2. The effect of TSLL on gastric carcinoma cells viability. To determine whether TSLL exhibited cytotoxic effects on gastric carcinoma cells, SGC-7901 (A) and HGC-27 cells (B) were treated with different concentration $(0,25,50,100,200$ and $400 \mu \mathrm{g} / \mathrm{mL})$ and CDDP $(4 \mu \mathrm{g} / \mathrm{mL})$, CCK 8 assay was performed at 24,48 or $72 \mathrm{~h}$ after treatment. The IC50 values were calculated (C). The values represent the means \pm SD of at least three independent experiments, ${ }^{*} p<0.05,{ }^{* * *} p<0.01,{ }^{* * * *} p<0.001$. 
As we know, Bcl-2 family proteins (Bcl and Bax) serve as important regulators involved in apoptosis [10]. And the equilibrium between pro-apoptotic and anti-apoptotic Bcl-2 family proteins is an essential element of the cell apoptosis. As shown in Fig. 6, the levels of Bcl-2 in SGC-7901 and HGC-27 cells decreased after TSLL (200 and $400 \mu \mathrm{g} / \mathrm{mL}$ ) treatment, compared to the control cells. In addition, the level of Bax was up-regulated both in SGC-7901 and HGC-27 cells with TSLL treatment (Fig. 5C and 5D).

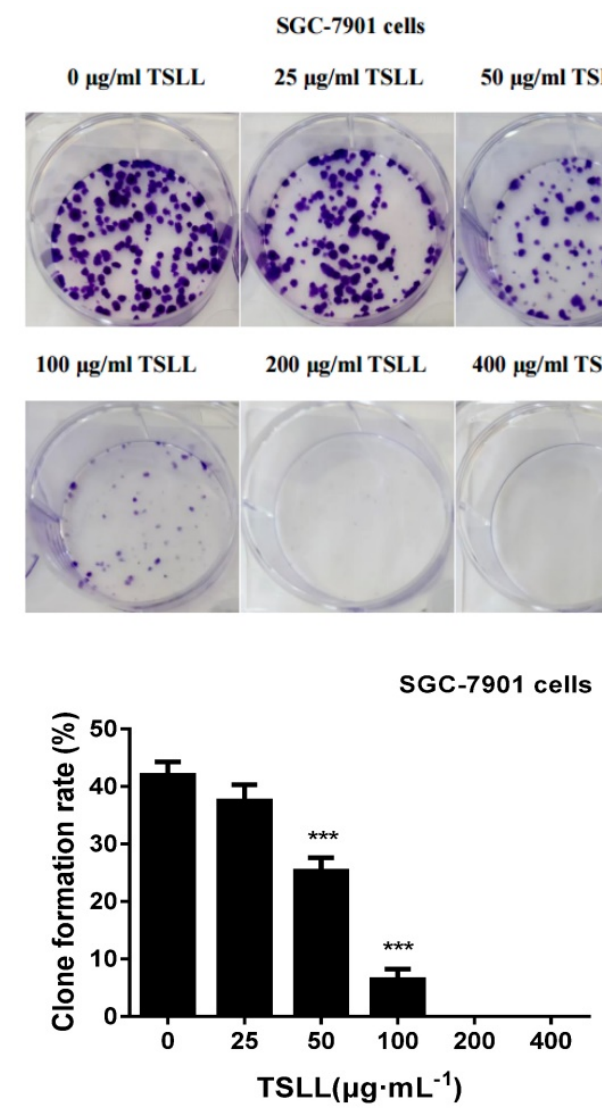

(A)

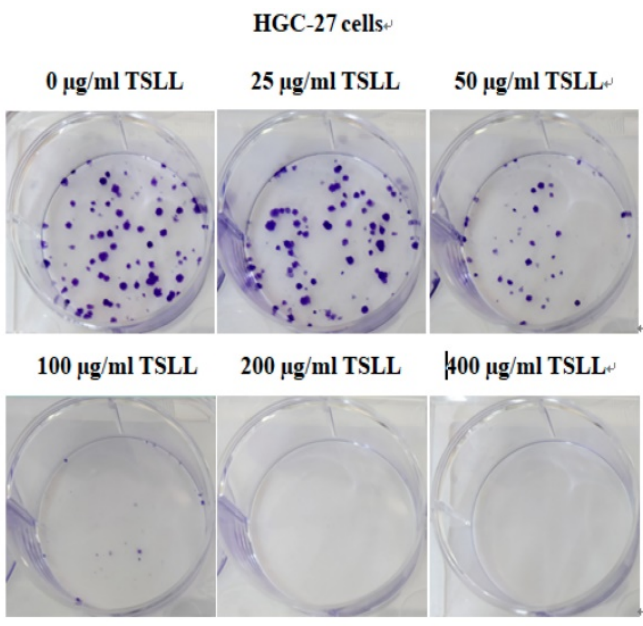

HGC-27 cells

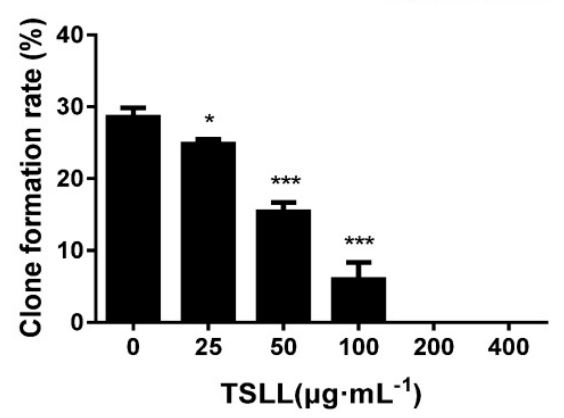

(B)

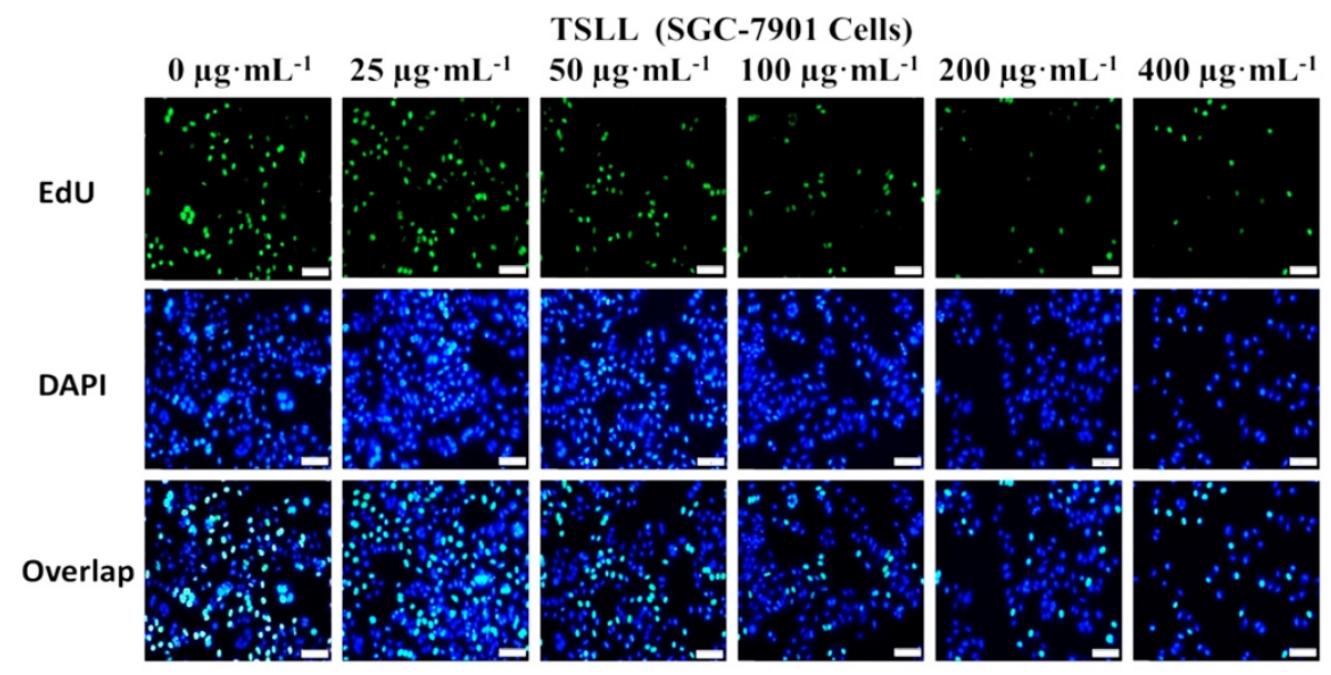

(C) 


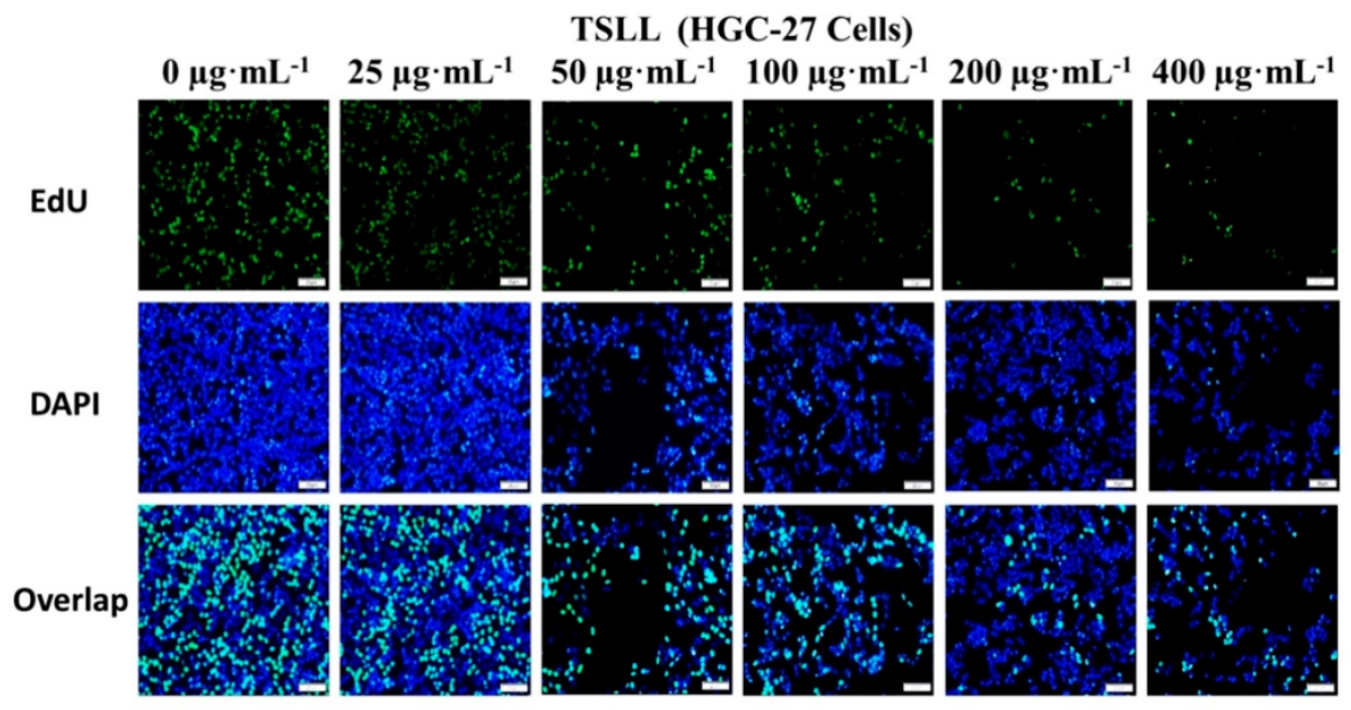

(D)

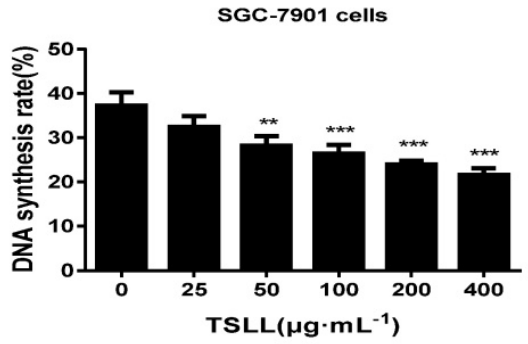

(E)

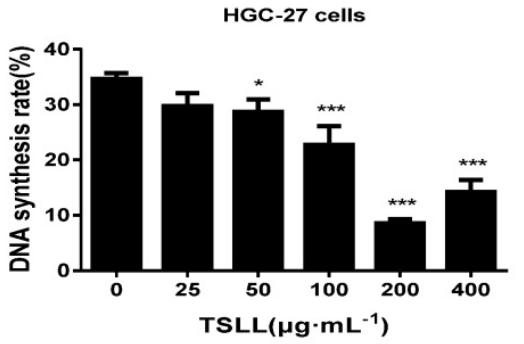

(F)

Figure 3. TSLL inhibited the proliferation and colony formation of gastric carcinoma cells. TSLL treatment reduced colony formation of SGC-7901 (A) and HGC-27 cells (B). After TSLL treatment for $24 \mathrm{~h}$, viable cells were counted and the relative clone formation rate was calculated according to the ratio of the number of cell clones to total number of inoculated cells. EdU staining was used to determine DNA synthesis in SGC-7901 (C) and HGC-27 cells (D). The fluorescence was observed under inverted fluorescence microscope after Edu staining. Quantification of DNA synthesis was analyzed $(E, F)$. The data represented means $\pm S D$. ${ }^{*} p<0.05$, ${ }^{* * *} p<0.01,{ }^{* * * *} p<0.001$, and the difference between TSLL-treated groups and the control was statistically significant.

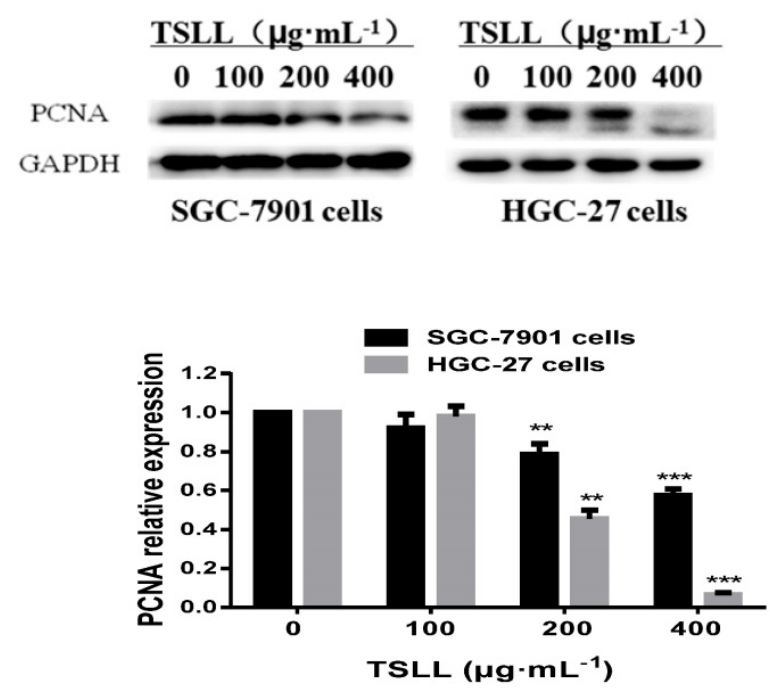

(A)
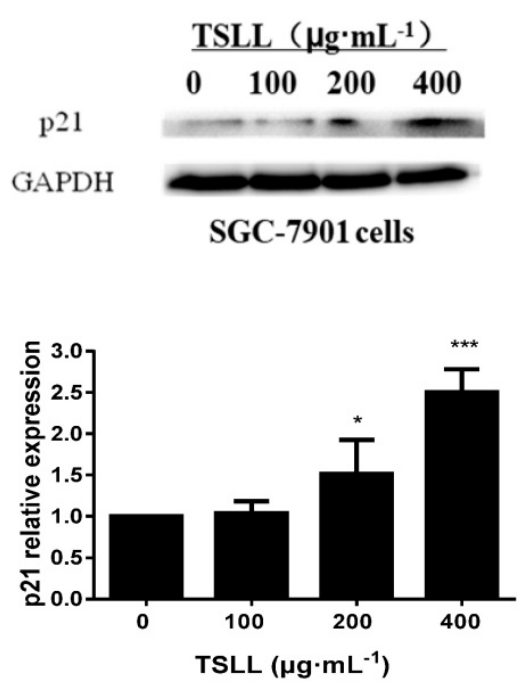

(B)

Figure 4. TSLL up-regulated $\mathrm{p} 21$ and down-regulated PCNA expression in gastric carcinoma cells. The expression of PCNA was detected by Western blotting analysis (A). The expression of p21 was also determined in SGC-7901 cells treated with TSLL (B). Quantitative results of PCNA and p21 levels, which were adjusted with GAPCH protein level. The data represent means $\pm S D .{ }^{*} p<0.05,{ }^{* *} p<0.01,{ }^{* * * * *} p<0.001$, significant difference between TSLL-treated groups and the control. 


\section{TSLL inhibits migration and invasion of gastric carcinoma cells}

Migration and invasion are key steps during the development of cancer. In the present study, wound healing assay showed that the inhibitory effects of TSLL on migration increased in a dose-dependent manner in SGC-7901 and HGC-27 cells after TSLL treatment for 12 and $24 \mathrm{~h}$ (Fig. 6A and 6B). Consistent with the migration results, TSLL also impaired the capability of SGC-7901 and HGC-27 cells to pass through the artificial basement membrane significantly $(P<0.05, P<0.01)$.

\section{TSLL promotes TIMP-1 expression and suppresses MMP-2 expression in gastric carcinoma cells}

The invasion and metastasis of gastric carcinoma cells were closely related to the abnormal expression of matrix metalloproteinases (MMPs) [11, 12] and its inhibitory factors (TIMPs) [13]. The data showed that TSLL treatment led to a reduction of MMP-2 expression (Fig. 7A) and an increase of TIMP-1 expression (Fig. 7B) in SGC-7901 and HGC-27 cells. Generally, malignant tumors, especially epithelial tumors, often undergo epithelial-mesenchymal transformation (EMT) to promote the invasion and metastasis of cancers [14, 15]. EMT confers vital properties to cancer cells for invasion and metastatic dissemination, especially increased motility, invasiveness and the ability to degrade components of the extracellular matrix (ECM) [16]. We further examined the effect of TSLL treatment on the expression of EMT-related proteins in gastric carcinoma cells. Unexpectedly, TSLL intervention had no significant effect on the expression of E-Cad (Fig. 7C) and Vim (Fig. 7D) protein in SGC-7901 and HGC-27 cells. The results implied that TSLL might inhibit the cancer invasion and metastasis through mechanisms other than EMT, such as reducing the accumulation of cancer stem cells, maintaining cancer microenvironment homeostasis and so on. The detailed mechanism needs further investigating.
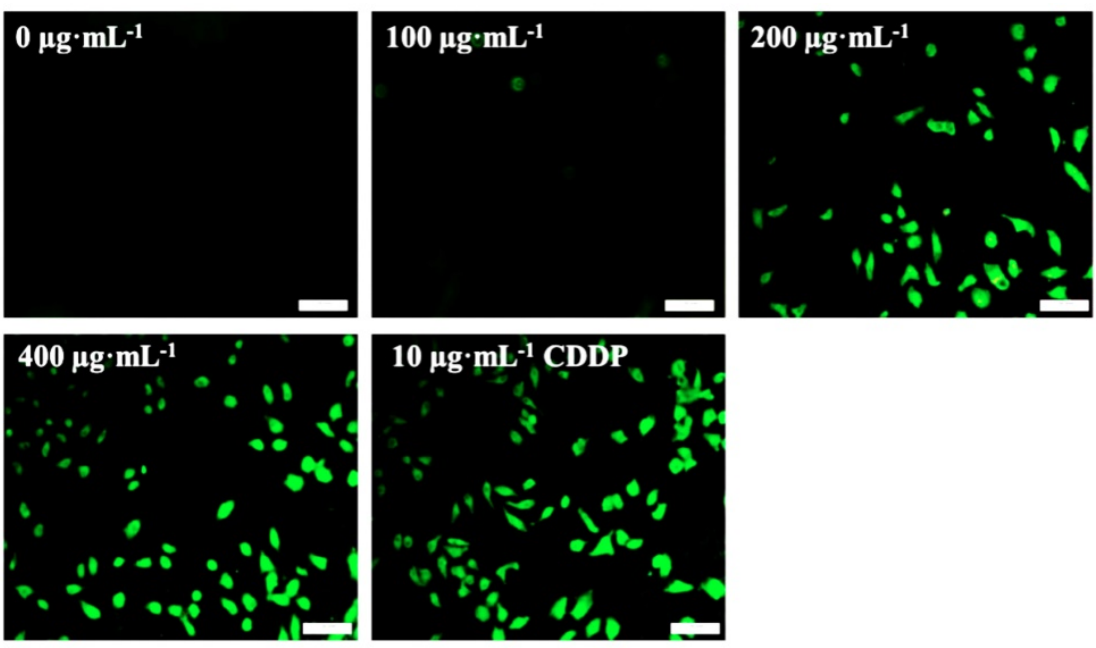

(A)
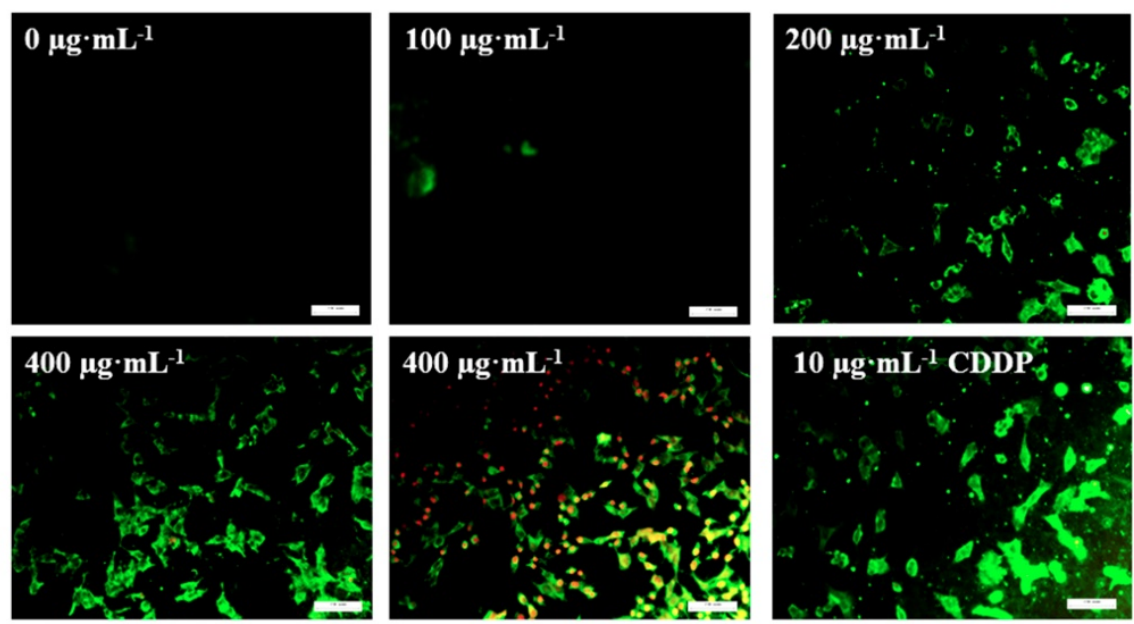

(B) 

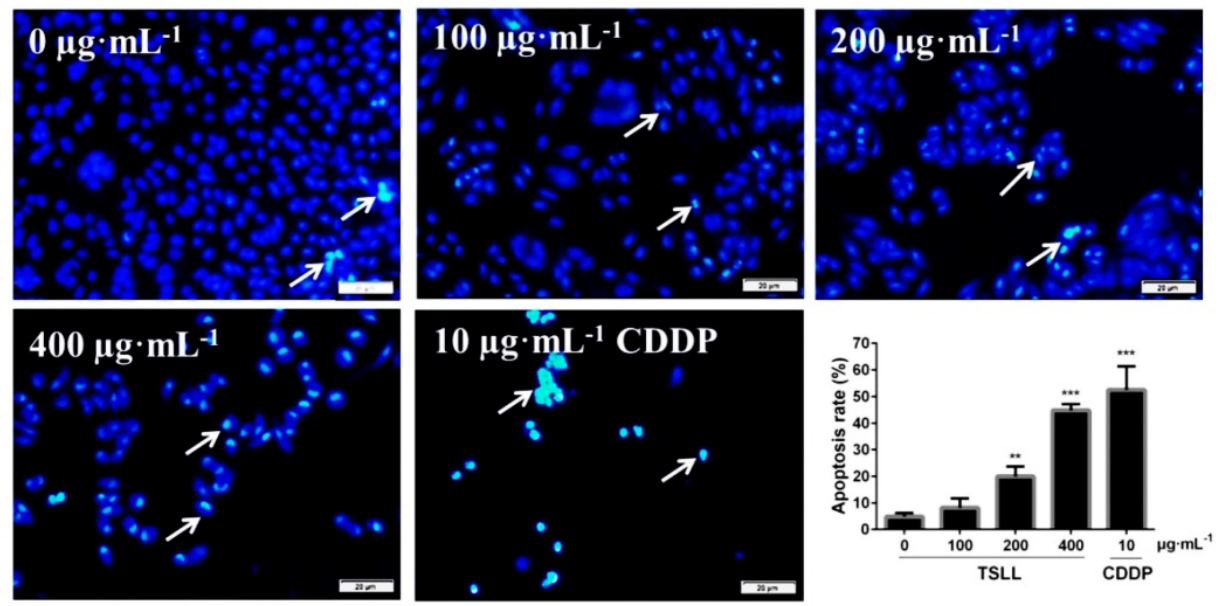

(C)
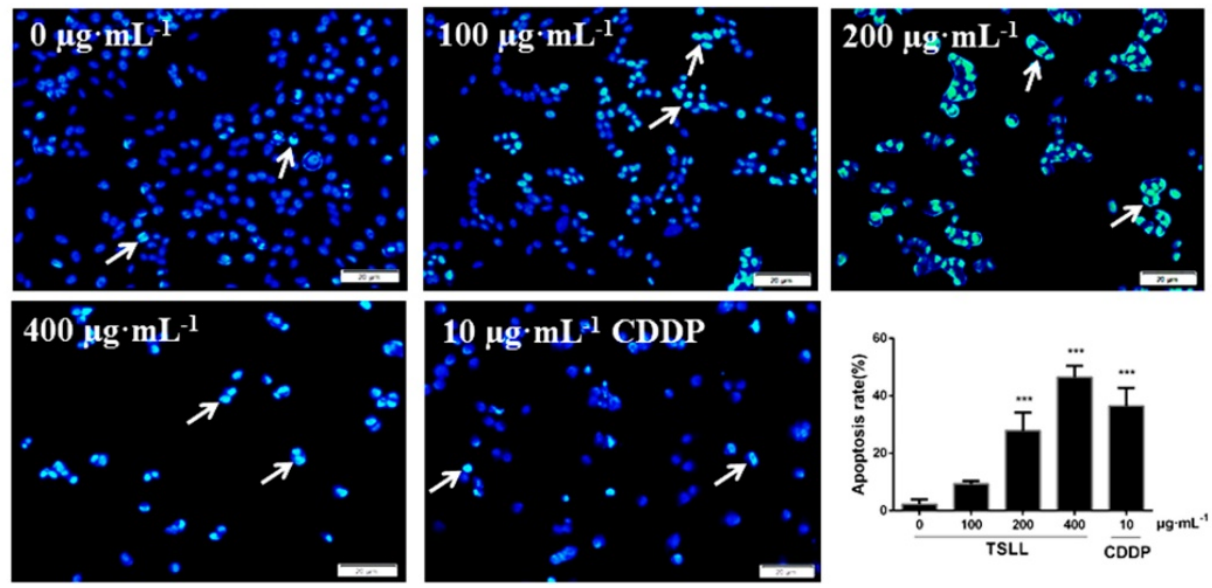

(D)
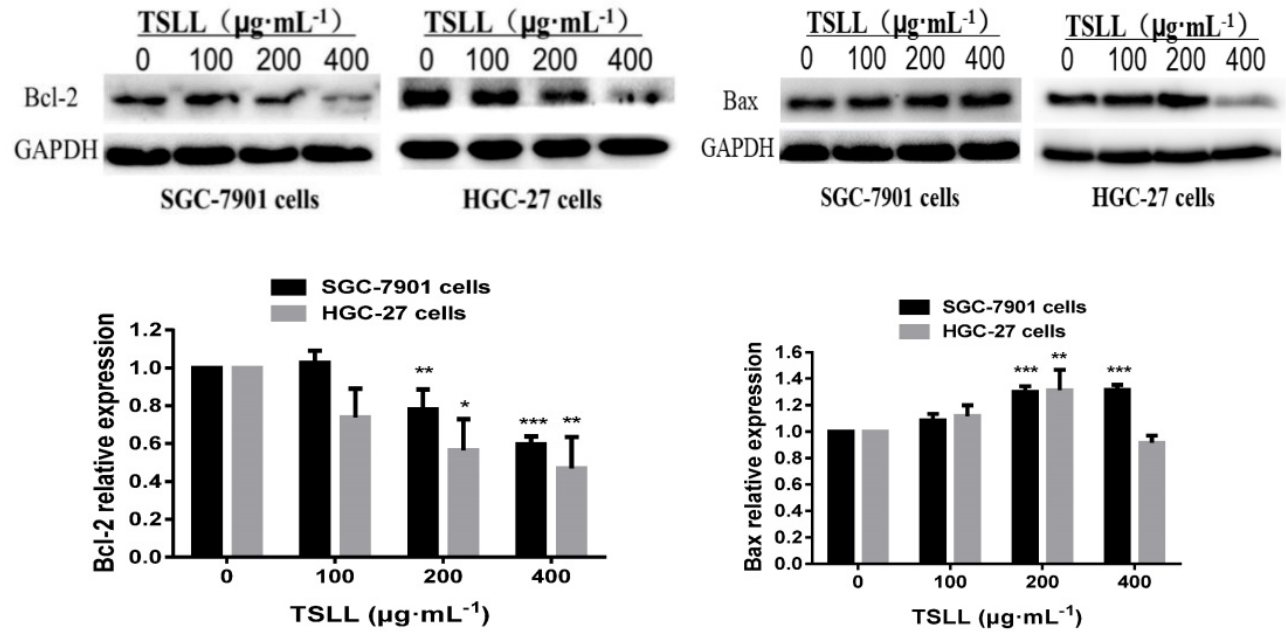

(E)

(F)

Figure 5. TSLL induced cells apoptosis in gastric carcinoma cells. Annex V/Pl double staining assay was applied to detect the apoptotic cells in SGC-7901 (A) and HGC-27 (B) cells. The effect of TSLL on apoptosis in SGC-7901 (C) and HGC-27 (D) cells was examined by using Hoechst 33342 staining. Fragmented nuclei were emphasized by white arrows. Western blotting was performed to analyze the protein levels of Bcl-2 (E) and Bax (F) in SGC-7901 and HGC-27 cells. GAPDH was used as a loading control. The data represent means \pm SD. ${ }^{*} p<0.05,{ }^{*} p<0.01,{ }^{* * * *} p<0.001$, significant difference between TSLL-treated groups and the control. 


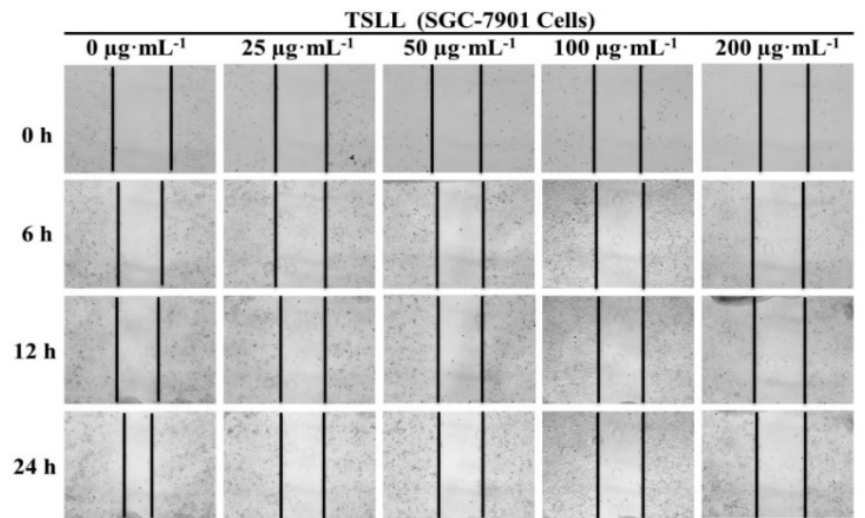

(A)

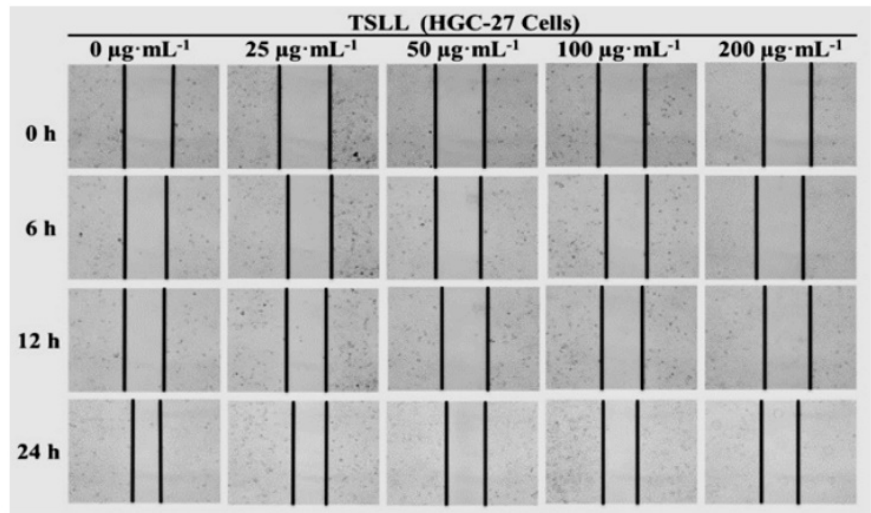

(B)

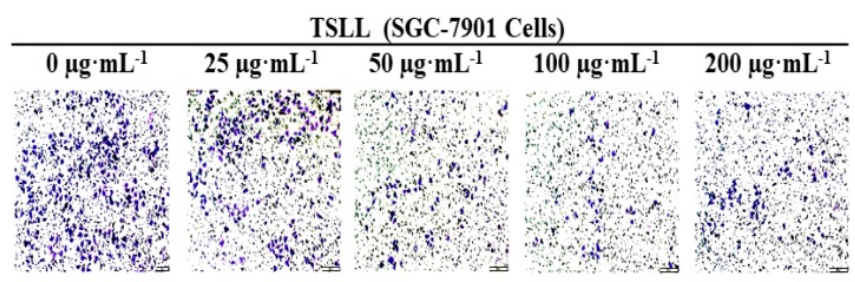

(C)

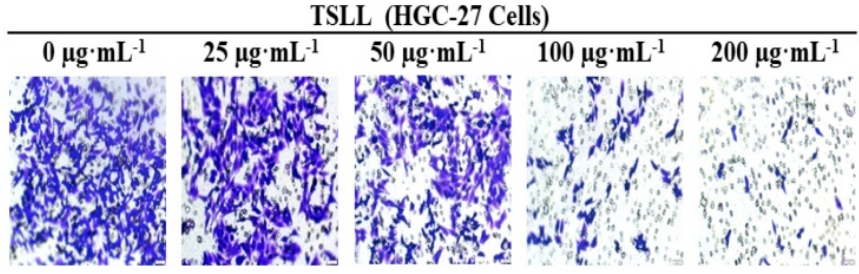

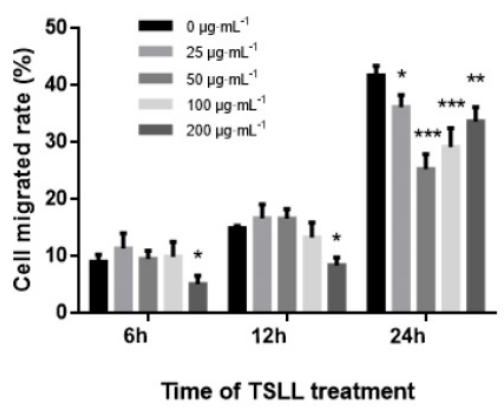
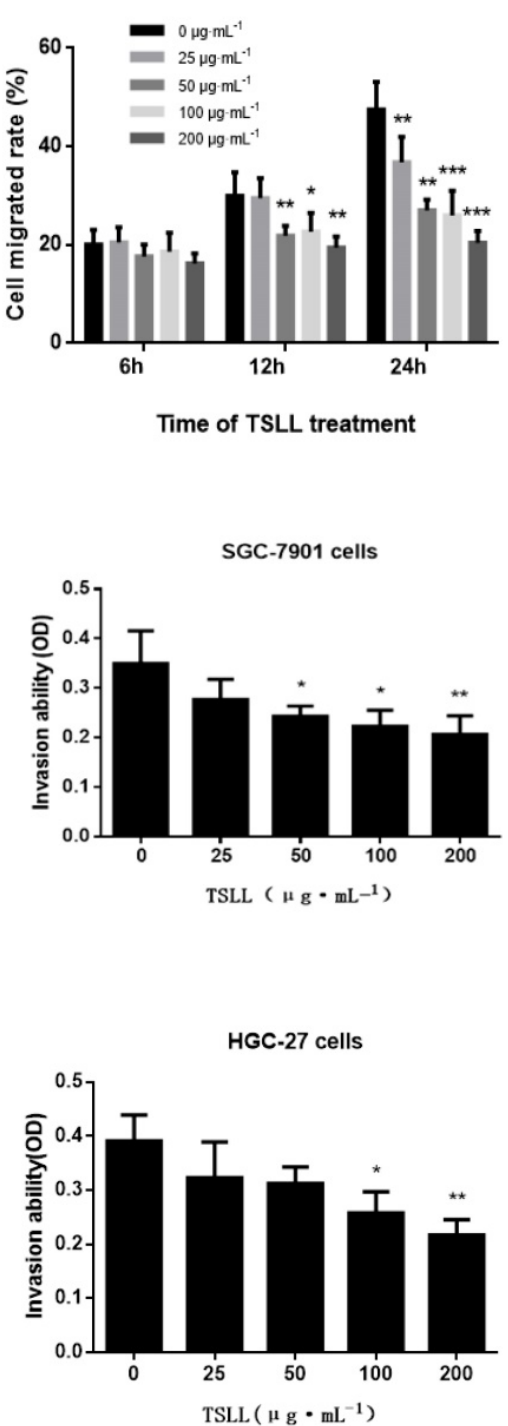

(D)

Figure 6. TSLL inhibited migration and invasion in the gastric carcinoma cells. Wound healing assays in SGC-7901 (A) and HGC-27 cells (B) after TSLL ( $0-200 \mu \mathrm{g} / \mathrm{mL})$ treatment for $24 \mathrm{~h}$. The inhibitory effect of TSLL on SGC-7901 (C) and HGC-27 cells (D) invasion was detected by a transwell assay. Representative images showed invasion of matrigel membranes stained with $0.5 \%$ crystal violet. The data represent means \pm SD. ${ }^{*} p<0.05,{ }^{* * *} p<0.01,{ }^{* * * *} p<0.001$, significant difference between TSLL-treated groups and the control. 

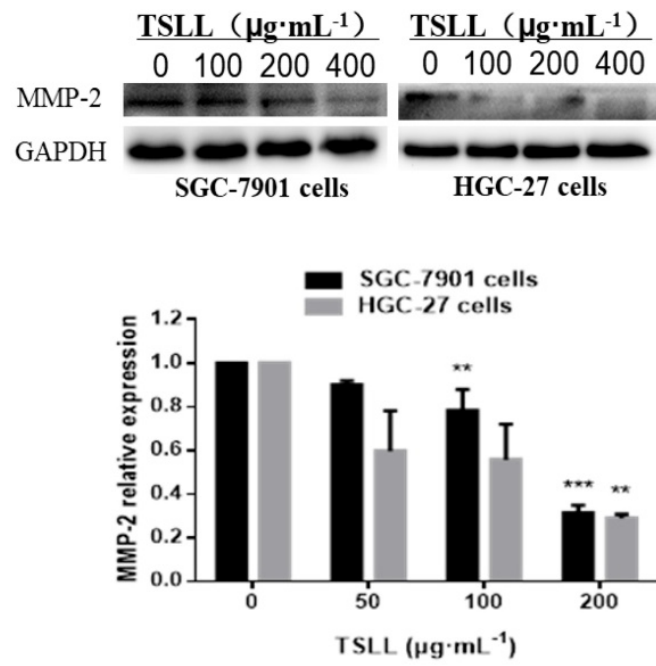

(A)

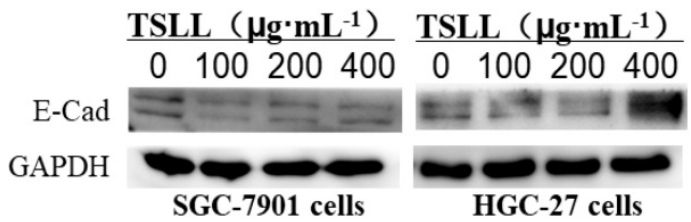

(C)

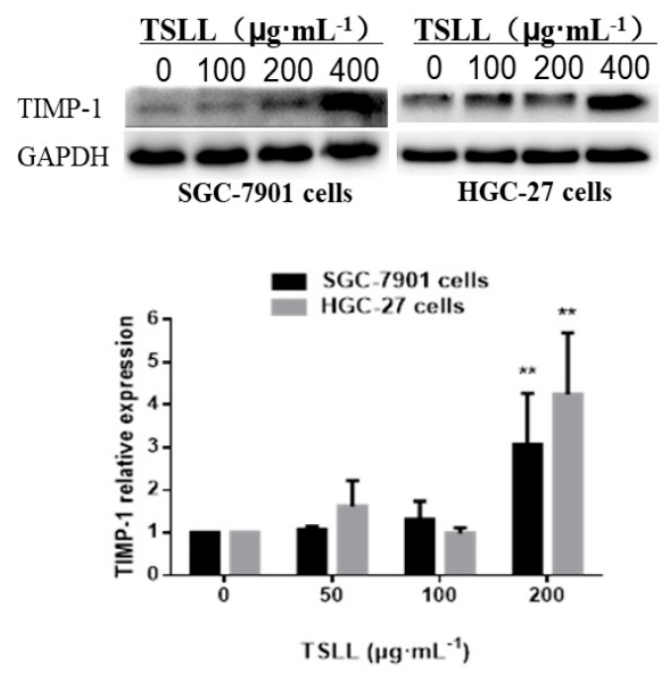

(B)

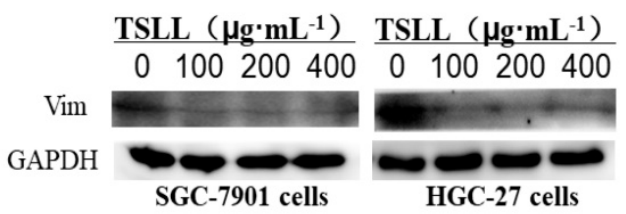

(D)

Figure 7. Analysis of the protein levels of MMP-2 (A), TIMP-1 (B), E-Cad (C) and Vim (D) in SGC-7901 and HGC-27 cells by Western blotting. Quantitative results of protein levels, which were adjusted with GAPDH protein level. The values represented the protein expression levels of at least three independent experiments. The data represent means \pm SD. ${ }^{* *} p<0.01,{ }^{* * *} p<0.001$, significant difference between TSLL-treated groups and the control.

\section{Discussion}

Cancer remains one of the deadliest diseases in the world and chemotherapy is still a major strategy. However, the efficacy of chemotherapy is often limited by adverse effects in normal tissues, especially serious toxicities and drug resistance [17, 18]. An increasing number of anti-cancer compounds from natural products provide a promising alternative to the chemoprevention and chemotherapy because of their favored safety and multi-target effects [19]. In the present study, we applied the extraction and purification of TSLL and firstly demonstrated that TSLL could effectively suppress gastric carcinoma cells proliferation and metastasis, and induce cells apoptosis. TSLL inhibited the proliferation of gastric carcinoma cells by decreasing PCNA levels, and induced apoptosis by up-regulating the expression of Bax and down-regulating the expression of Bcl-2. Previous studies have shown statistically significant differences in PCNA expression between normal gastric mucosa and gastric carcinoma. During the transition from normal gastric mucosa to gastric carcinoma, PCNA expression gradually increases [20]. In the TCGA database, the expression of PCNA in gastric carcinoma tissues is higher than that in normal tissues, further confirming that downregulation of
PCNA levels can inhibit gastric carcinoma cells proliferation. In addition, Anagnostopoulos GK et al. found that low expression of Bax in gastric carcinoma was associated with low 5-year survival and poor clinical prognosis [21].

In the 1965s, Lauren suggested that gastric carcinoma could be classified into intestinal and diffuse types according to the degree of differentiation and biological behavior [22]. Intestinal type gastric carcinomas are caused by gastric mucosal atrophy and intestinal metaplasia caused by chronic helicobacter pylori infection, while diffuse type gastric carcinomas are considered to be arise from an abnormality of stem-like cells [23]. Recent studies show that the cancer stem cell (CSC) markers, such as $A B C B 1$ and CD133, were expressed higher in the diffuse type than in the intestinal type of human gastric carcinoma. CSC markers were also expressed higher in the undifferentiated cell line HGC-27 than the moderately-poorly differentiated cell line SGC-7901, which indicated that HGC-27 exhibited typical characteristics of diffuse gastric carcinoma. Compared to intestinal type gastric adenocarcinomas, the poorly-differentiated diffuse type gastric carcinoma showed more advanced stages, such as lymph node metastasis and vascular invasion [24]. Herein, our data showed that the proliferation of 
SGC-7901 and HGC-27 cells was inhibited by high concentration of TSLL, and undifferentiated HGC-27 cells were more sensitive to TSLL treatment. In addition, the apoptotic induction rate of HGC-27 was higher than SGC-7901 cells. These results demonstrated that TSLL has a strong anti-cancer effect on SGC-7901 and HGC-27 cells, and has potential therapeutic effect on malignant diffuse.

Chemotherapy resistance and high recurrence rate of diffuse type gastric carcinoma are largely dependent on the aggressive cancer behavior, which is also important for the treatment of poorly differentiated malignant cancers [25]. There are two key factors during the process of cancer invasion and metastasis: MMP-2 and TIMP-1. It has been reported that high expression of epithelial MMP-2 in gastric carcinoma is associated with low survival, while aggressive gastric carcinoma is associated with low expression of TIMP [26, 27]. In gastric carcinoma, either inhibition of MMP-2 or up-regulation of TIMP-1 expression has been reported to suppress of metastasis [28, 29]. Initially, metastatic cancer cells need to detach from the primary tumor, migrate and invade the basement membrane. MMPs can facilitate stromal and vascular invasion of cancer cells through the degradation of the extracellular matrix, play a crucial role in cancer metastasis steps [30]. Here, TSLL successfully suppressed the migration and invasion of gastric carcinoma cells by decreasing the expression of MMP-2 and elevating the expression of TIMP-1. Besides, it has reported that MMP-2 and TIMP-1 are important regulatory proteins in EMT [31, 32]. The critical mechanism of cancer progression and metastasis is the re-activation of the EMT [33, 34]. However, another interesting observation showed that TSLL had no significant effect on EMT in gastric carcinoma cells which indicate TSLL might inhibit the invasion and metastasis of cancer by inhibiting other mechanisms besides EMT. Combined with the high sensitivity of undifferentiated gastric carcinoma cells to the anti-tumor effect of TSLL, the inhibitory effect of TSLL on invasion and migration of gastric carcinoma might be mediated by targeting cancer stem cells and inhibiting the enrichment of cancer stem cells $[35,36]$.

In conclusion, TSLL exerts its anticancer activity by inhibiting cell proliferation, migration and invasion, and inducing apoptosis in gastric carcinoma cells. Moreover, TSLL exhibit a stronger anticancer activity in undifferentiated gastric carcinoma cells, contributed to the treatment of diffuse-type gastric carcinoma. Future studies will be needed to on the potential mechanism of interaction between gastric carcinoma cell and TSLL, and the anti-gastric carcinoma effect of TSLL needs to be verified through in vivo animal experiments. Thus, TSLL may be used as an alternative or adjuvant to chemotherapeutic agents in gastric carcinoma treatment to reduce drug resistance and prognostic risk, and provide an attractive anticancer strategy for targeting diffuse-type gastric carcinoma.

\section{Acknowledgments}

This work is supported by grants from the National Natural Sciences Foundation of China (No. 819736668, No. 81774130, No. 81270359, and No. 81000946), the National Science Fund of Hunan Province for Distinguished Young Scholars (No. 2018JJ1018), Open Funds of State Key Laboratory of Oncology in South China (HN2019-07), and the First-Class Discipline of Pharmaceutical Science of Hunan.

\section{Competing Interests}

The authors have declared that no competing interest exists.

\section{References}

1. Bray F, Ferlay J, Soerjomataram I, et al. Global cancer statistics 2018: GLOBOCAN estimates of incidence and mortality worldwide for 36 cancers in 185 countries. CA Cancer J Clin 2018; 68:394-424.

2. Yoo C, Ryu MH, Park YS, et al. Intraoperatively assessed macroscopic serosal changes in patients with curatively resected advanced gastric cancer: clinical implications for prognosis and peritoneal recurrence. Ann Surg Oncol 2015; 22:2940-2947.

3. Zong L, Abe M, Seto $\mathrm{Y}$. The challenge of screening for early gastric cancer in China. Lancet 2016; 388:2606.

4. Munafo JP. Chemistry and biological activity of steroidal glycosides from the Lilium genus. Nat Prod Rep 2015; 32:454-477.

5. Zhou ZL, Feng ZC, Fu CY, et al. Steroidal and phenolic glycosides from the bulbs of Lilium pumilum DC and their potential Na+/K+ ATPase inhibitory activity. Molecules 2012; 17:10494-10502.

6. Wang $\mathrm{T}$, Huang $\mathrm{H}$, Zhang $\mathrm{Y}$, et al. Role of effective composition on antioxidant, anti-inflammatory, sedative-hypnotic capacities of 6 common edible Lilium varieties. J Food Sci 2015; 80:H857-68.

7. Li W, Wang Z, Zha L, et al. HMGA2 regulates epithelial-mesenchymal transition and the acquisition of tumor stem cell properties through TWIST1 in gastric cancer. Oncol Rep 2017; 37:185-192.

8. Karimian A, Ahmadi Y. Multiple functions of p21 in cell cycle, apoptosis and transcriptional regulation after DNA damage. DNA Repair (Amst) 2016; 42:63-71.

9. Parveen A, Akash MS, Rehman K. Dual Role of p21 in the Progression of Cancer and Its Treatment. Crit Rev Eukaryot Gene Expr 2016; 26:49-62.

10. Hassan M, Watari H, AbuAlmaaty A, et al. Apoptosis and molecular targeting therapy in cancer. Biomed Res Int 2014; 2014:150845.

11. Yao Z, Yuan T, Wang H, et al. MMP-2 together with MMP-9 overexpression correlated with lymph node metastasis and poor prognosis in early gastric carcinoma. Tumour Biol 2017; 39:1010428317700411.

12. Zheng H, Takahashi H, Murai Y, et al. Expressions of MMP-2, MMP-9 and VEGF are closely linked to growth, invasion, metastasis and angiogenesis of gastric carcinoma. Anticancer Res 2006; 26:3579-3583.

13. Alpízar-Alpízar W, Laerum OD, Christensen IJ, et al. Tissue Inhibitor of Metalloproteinase-1 Is Confined to Tumor-Associated Myofibroblasts and Is Increased With Progression in Gastric Adenocarcinoma. J Histochem Cytochem 2016; 64:483-494.

14. Wang $\mathrm{S}, \mathrm{Han} \mathrm{H}, \mathrm{Hu} \mathrm{Y}$, et al. MicroRNA-130a-3p suppresses cell migration and invasion by inhibition of TBL1XR1-mediated EMT in human gastric carcinoma. Mol Carcinog 2018; 57:383-392.

15. Yoon $\mathrm{C}$, Cho SJ, Chang $\mathrm{KK}$, et al. Role of Rac1 Pathway in Epithelial-to-Mesenchymal Transition and Cancer Stem-like Cell Phenotypes in Gastric Adenocarcinoma. Mol Cancer Res 2017; 15:1106-1116.

16. Gonzalez DM. Signaling mechanisms of the epithelial-mesenchymal transition. Sci Signal 2014; 7:re8.

17. Kanda K. [The Necessity and the Current Status of Safe Handling of Anticancer Drugs]. Gan To Kagaku Ryoho 2017; 44:545-549. 
18. D'Alterio C, Scala S, Sozzi G, et al. Paradoxical effects of chemotherapy on tumor relapse and metastasis promotion. Semin Cancer Biol 2019; S1044-579X:30174-30179.

19. Kinghorn AD, DE Blanco EJ, Lucas DM, et al. Discovery of Anticancer Agents of Diverse Natural Origin. Anticancer Res 2016; 36:5623-5637.

20. $\mathrm{Hu} \mathrm{L}, \mathrm{Li} \mathrm{HL}, \mathrm{Li} \mathrm{WF}$, et al. Clinical significance of expression of proliferating cell nuclear antigen and E-cadherin in gastric carcinoma. World J Gastroenterol 2017; 23:3721-3729.

21. Anagnostopoulos GK, Stefanou D, Arkoumani E, et al. Expression of Bax protein in gastric carcinomas. A clinicopathological and immunohistochemical study. Acta Gastroenterol Belg 2007; 70:285-289.

22. LAUREN P, THE TWO HISTOLOGICAL MAIN TYPES OF GASTRIC CARCINOMA: DIFFUSE AND SO-CALLED INTESTINAL-TYPE CARCINOMA. AN ATTEMPT AT A HISTO-CLINICAL CLASSIFICATION. Acta Pathol Microbiol Scand 1965; 64:31-49.

23. Ming SC. Cellular and molecular pathology of gastric carcinoma and precursor lesions: A critical review. Gastric Cancer 1998; 1:31-50.

24. Marqués-Lespier JM, González-Pons M. Current Perspectives on Gastric Cancer. Gastroenterol Clin North Am 2016; 45:413-428.

25. Nakamura R, Omori T, Mayanagi S, et al. Risk of lymph node metastasis in undifferentiated-type mucosal gastric carcinoma. World J Surg Oncol 2019; 17:1-8.

26. Nakata B, Muguruma K, Hirakawa K, et al. Predictive value of Bcl-2 and Bax protein expression for chemotherapeutic effect in gastric cancer. A pilot study. Oncology 1998; 55:543-547.

27. Zhang M, Zhu GY, Gao HY, et al. Expression of tissue levels of matrix metalloproteinases and tissue inhibitors of metalloproteinases in gastric adenocarcinoma. J Surg Oncol 2011; 103:243-247.

28. Gurgel DC, Valença-Junior JT, Dornelas CA, et al. Immunoexpression of metalloproteinases 2 and 14 and TIMP-2 inhibitor in main types of primary gastric carcinomas and lymph node metastasis. Pathol Oncol Res 2015; 21:73-81.

29. Peduk S, Dincer M, Tatar C, et al. THE ROLE OF SERUM CK-18, MMP-9 AND TIPM-1 LEVELS IN PREDICTING R0 RESECTION IN PATIENTS WITH GASTRIC CANCER. Arq Bras Cir Dig 2018; 31:e1401.

30. Löffek S, Schilling O. Series "matrix metalloproteinases in lung health and disease": Biological role of matrix metalloproteinases: a critical balance. Eur Respir J 2011; 38:191-208.

31. Duong TD. MMP-2 plays an essential role in producing epithelial-mesenchymal transformations in the avian embryo. Dev Dyn 2004; 229:42-53.

32. D'Angelo RC, Liu XW, Najy AJ, et al. TIMP-1 via TWIST1 induces EMT phenotypes in human breast epithelial cells. Mol Cancer Res 2014; 12:1324-1333.

33. Chaffer CL, San Juan BP, Lim E. EMT, cell plasticity and metastasis. Cancer Metastasis Rev 2016; 35:645-654.

34. Singh M, Yelle N, Venugopal C.EMT: Mechanisms and therapeutic implications. Pharmacol Ther 2018; 182:80-94.

35. Nguyen DX, Bos PD. Metastasis: from dissemination to organ-specific colonization. Nat Rev Cancer 2009; 9:274-284.

36. Peitzsch C, Tyutyunnykova A, Pantel K. Cancer stem cells: The root of tumor recurrence and metastases. Semin Cancer Biol 2017; 44:10-24. 